\title{
What was Takechi Kabuki?
}

\author{
Ryûichi Kodama \\ Translated by Riyo Namigata
}

\begin{abstract}
Takechi Tetsuji (1912-1988), a kabuki and bunraku director and critic whose experimental "Takechi Kabuki" was much praised for its putative faithfulness to the original productions while it was harshly criticized by some critics for its free-almost arbitrary-interpretations of the "traditions" on which Takechi boastfully declared it to be based. This paper classifies the kabuki and bunraku plays Takechi produced into four periods and argues that the mixed reactions to them should be accounted for by a common tendency to confuse and conflate the approaches and styles Takechi adopted in each period by sketching out his disparate and sometimes incompatible theories, methods and praxis. This paper's ultimate aim is to demystify the often selfmystifying Takechi and his misunderstood productions and writings so as to provide historical perspectives and more comprehensive understanding to evaluate his contributions to promoting and enriching traditional performing arts. By so doing, I also contend that examining Takechi's modernist attempts to "return to the origin" would reveal that such origin(s) did not exist.
\end{abstract}

\section{Introduction}

The difficulty of describing Takechi Tetsuji (1912-1988) comes from the sheer range of his work. He was well versed in classical theatre and was a theorist and director who tried to innovate kabuki performances after World War II. Apart from this familiar facet of Takechi, he was also a director of operas and soft pornography films. In addition to this, he was a novelist, a horse racing commentator, an expert on Japanese art (who even ran a gallery himself), a huge collector of classic records (beyond doubt), a strong anti-American (when Mishima Yukio committed suicide, he commented that it had something to do with the CIA's conspiracies) and, although it is uncertain how serious he was, he had even attempted to become a politician by running as a candidate for the Liberal Democratic Party in the House of Councillors election.

Prolificacy has been a prerequisite for great artists since olden times, and Takechi's wide range of work fulfills this condition. However, the extensiveness of his work also incurred criticism. Another one of the difficulties in discussing Takechi is in how to address the various criticisms he received. Furthermore, in Takechi's case, the indecipherable seriousness of his insolent remarks hand in hand with his excessive willingness to satisfy others tended to further beckon criticism.

It can be found that quite a few critics fully approve of Takechi up until a certain period but flatly deny him from another period onward, as is often the case with evaluating great people. All in all, we can consider these critiques to be about "my Takechi Tetsuji" as reflected in the mirror or "me when 
I used to meet with Takechi Tetsuji."

Those who met Takechi at the start of the 1950 grasp on to this privilege; those who made it to his new Kanjinchô production at the Nissei Theatre in 1963 consider it the monument to their own youth; and those who could only meet him in his later years after the 1980s never stop raving over the afterglow of his brilliant career, as if embracing their good luck at having been able to meet him. These are all truths in their own ways, and the issue is not about who is right or wrong. The most notable condition accounting for these differences is unquestionably the period at which these individuals encountered Takechi Tetsuji, and there is no room for an "objective," "correct," or "consistent" portrait of Takechi Tetsuji.

Thus, in this paper, I would like to propose a perspective for a current-day understanding of Takechi Tetsuji by dividing his kabuki works into four phases, focusing especially on his activities during the first phase in order to evaluate the achievements of this brilliantly contradictory man.

\section{Classification of the Takechi Kabuki Periods}

Because Takechi Tetsuji continued to ardently produce kabuki plays into his last years, it has been misunderstood that "kabuki plays produced by Takechi Tetsuji" are all "Takechi Kabuki," as if they all followed a single method. Kabuki plays produced by Takechi, however, can be classified into at least four periods. ${ }^{(1)}$

(1) Although there are slight omissions, Gondô Yoshikazu's Takechi Tetsuji no kabuki enshutsu (Takechi Tetsuji's Kabuki Direction) (Issue 3 of Kabuki kenkyûu to hihyôō, published July 1989) is convenient for use as a comprehensive overview of kabuki directed by Takechi Tetsuji. Additionally, of the many commentaries on Takechi, the following three may be considered the most valid:

1. Dômoto Masaki's Kari no hane no kagayaki, as an homage to Takechi's life.

2. Gondô Yoshikazu's Takechi Tetsuji shiryô shûsei (Collection of Documents on Takechi Tetsuji), as a monumental compilation of Takechi's records.

3. From the posthumous memorials, Matsui Kesako's "Kindai” no gyakushû (Modern Times' Counterattack), as a fine example of analysis.

First, Dômoto's book was written as a commentary on Takechi Tetsuji's Kari no hane (February 1969, Gakugei Shorin). It was later reproduced in Dômoto's Dentô engeki to gendai (Classical Theatre and Contemporary Times) (1971, San-ichi Shôbô). The experience, inspiration, and elation felt by the first generation to be greatly influenced by Takechi can be found in this document.

Second, Gondô's work, since the 100th issue of the magazine Kamigata Geinô (Kamigata Performing Arts, April 1989), continues to be serialized today.

Third, Matsui's contribution, was compiled in the third issue of Kabuki kenkyû to hihyô (July 1989) and notes two important points that no one else has made. The first was the point that what Takechi Tetsuji strove towards was not "densho geinô" (traditional entertainment) but "koten engeki" (classical theatre). This is an essential thesis for understanding Takechi Tetsuji as a theorist. The premise to this statement is the definition that "koten" (classicism) is not the simple accumulation of "densho" (tradition) that has been handed down, but is the result of consciously consolidating this accumulation based on a certain standard after exposing it to modern understandings.

Moreover, Matsui's states that Takechi also assumed the role of passing down traditions. Apart from kabuki, he also transmitted the traditions of nô, kyoggen, and bunraku, and it was because of this that he was accepted in the realm of kabuki. A unique observation made by Matsui, one of the people closest to Takechi in his later years, was that there were more than a few instances where information that was introduced as part of the actors' discussions on their art was later stated as Takechi's own opinion. For instance, in Kanshô shô, Takechi pointed out the skillfulness with which bunraku's Yoshida Bungorô entered the gate as Chiyo in Terakoya; this statement, however, actually repeated what Yoshida Eiza had told Takechi before the war. In other words, as a critique, it was cheating, but for future generations, it remained important testimony. 
The First Phase: Period from 1949-52. The narrow definition of "Takechi Kabuki."

The Second Phase: Period after 1952, when Takechi reconciled with Shôchiku and became a member of the Shôchiku Kabuki Council, or around the period when he worked on the play commemorating the opening of the Nissei Theatre.

The Third Phase: Period when Takechi's works centered on Tsuruya Nanboku's works such as Oguri hangan kuruma kaidô in 1974 and his "adaptation" (hotetsu) of three Nanboku plays at the Kabuki-za in May of 1976.

The Fourth Phase: Period focused on the Chikamatsu-za (leader Nakamura Senjaku II [later Sakata Tôjûrô IV, 1931-]).

To begin with, the name "Takechi Kabuki" was adopted as the title of a book by Takechi Tetsuji himself and further, because of the fact that his collection of works was also entitled Teihon Takechi Kabuki (The Standard Edition Takechi Kabuki), this name was used whenever Takechi was involved in kabuki. However, as has been periodically mentioned, Takechi Kabuki was a name coined by the media that Takechi later adopted himself. The first record of its use is likely the statement, "I heard somebody say 'Takechi Kabuki' following the example of 'Mitsukoshi Kabuki' [performed at the Mitsukoshi Theatre in the Mitsukoshi Department Store located in Nihonbashi, Tokyo] and thought that was interesting." This statement, made by the moderator Hishida Masao during a tripartite talk with Takechi and Bandô Minosuke VI (later Bandô Mitsugorô VIII, 1906-1975), was published in the pamphlet for the Kansai jikken gekijô dai rokkai kôen wakate kabuki (Kansai Experimental Theatre Sixth Showing: Kabuki from the Younger Generation) performed at the Bunraku-za in December of 1949. It may thus be concluded that the name "Takechi Kabuki" was in use before the first show by the name.

Even after this production, the January 1950 issue of Makuai (Interlude) published the following month included the comment, "I think this may be called Takechi Kabuki." Seki Itsuo, Makuai's managing editor had made this comment during a joint review meeting ${ }^{(2)}$ attended by Takechi himself. Hishida was also present at this discussion; from this, we may conclude that the "somebody" who provided Hishida with the name "Takechi Kabuki" before the production may have been Seki

In any case, the narrow definition of "Takechi Kabuki" refers to kabuki directed by Takechi Tetsuji from 1949 to 1952, starring young actors like Bandô Tsurunosuke IV (later Nakamura Tomijûrô V, 1929-2011), Nakamura Senjaku II, and Jitsukawa Enjaku III (1921-1991), among others. The performances all took place in Osaka, Kyoto and Nagoya and did not reach Tokyo. After this, Takechi expanded out to genres other than kabuki and, after nearly ten years, he returned to Shôchiku's kabuki productions. In the meantime, Senjaku had risen to fame and Takechi, also in the limelight for helping to train Senjaku, published his book entitled Takechi Kabuki. In later years, further use of the word "Takechi Kabuki" as an advertising catchphrase would add to its confused meaning.

\section{Characteristics and Origin of First Phase Takechi Kabuki}

On a flyer thought to have been distributed before the showing of the first Takechi Kabuki is a statement made jointly by Takechi and Minosuke, declaring their purpose as "bringing kabuki pro-

(2) "Kansai jikken gekijô wakate kabuki gappyô zadankai" (The Kansai Experimental Theatre: Round-table Discussion and Joint Review of Kabuki by the Younger Generation) (Makuuchi, January 1950). 
duction, distorted by conventional actor-centric production styles, back to a script-centric, realistic style and establishing kabuki in its correct form as a cultural heritage and form of classical theatre."

Although they sounded overconfident in the declamation, it had its effects: in Kumagai jinya, for instance, an attempt at a complete performance was made from the prologue ( $h a b a$ ), which was usually cut out. The ending also abandoned the makusoto (scene continued outside the curtain after it is drawn) highlight scene where the main character, Kumagai, enters the hon hanamichi (permanent elevated passageway) alone; instead, the Kumagai couple enter the hon hanamichi while Fuji-no-kata and Midaroku, the other major characters, enter the kari hanamichi (temporary hanamichi), demonstrating the contrast between the two. The actor-centric highlight scene was thus removed as an impurity, and the scene was faithfully performed with greater adherence to the original jôruri script. This policy was followed meticulously: for instance, while, in usual kabuki productions, some lines are cut and others are changed in the scene where Yoshitsune reveals Midaroku's identity as a warrior of the Heike clan, Takechi demanded that the actors read the original text faithfully and breathe as little as possible to keep up pace.

The events during this time were described by Tomijûrô, who played Kumagai, in the following way: "I wondered what would happen, but the models used were bunraku chanter [Toyotake] Yamashiro no shôjô (1878-1967) and the puppeteer [Yoshida] Eiza II (1903-1974)". (3) Yamada Shôichi, who was present at the rehearsals, also testified that the scene where Kumagai exits the hanamichi was repeatedly practiced with a stopwatch in hand, with Takechi calling out to "walk in the same way as the Yamashiro no shôjô record!"

In other words, the foundations of Takechi's kabuki direction lay in gidayû bushi. ${ }^{(4)}$ This style was something Takechi had learnt from Kônoike Yoshitake when they jointly directed Taikôki Jûdanme (Ehon Taikôki Act 10 ["Amagasaki no ba"]) prior to the war.

Kônoike was Takechi's younger mentor and had taught him practical knowledge on bunraku. He was also heir to the Kônoike family, wealthy merchants since the Edo era. The head of the Kônoike family had, for generations, assumed the name "Kônoike Zen-emon." Kônoike's father was Zenemon Kônoike Zen-emon XI but, as Yoshitake was his fourth son, his eldest brother succeeded the name Kônoike Zen-emon XII.

Although both were very wealthy, Kônoike was the polar opposite of Takechi Tetsuji. ${ }^{(5)}$ These two

(3) A statement made in the discussion, "Nagareru kabuki wa ikite iru" (Flowing Kabuki is Living Kabuki), (Makuuchi, February 1950).

(4) The musical style of the traditional puppet theatre (bunraku), combining narrative chanting with shamisen playing.

(5) Takechi's father, Shôjirô, made his fortune from the great success of the Takechi building contractor's office, starting with his patent on the "Takechi construction method." According to the preface to the 66-page booklet, Tokkyo Takechishiki kiso kô ni tsuite (About the Patented Takechi-style Foundation Work), published February 15, 1932; "Takechi-style foundation work requires the driving of special reinforced concrete stakes into the ground through the use of a special method and, as foundation work that regenerates natural soft ground into solid new ground, this invention was completed in March 1927. This international-level invention of a construction method for foundations is patented in Japan, England, the U.S., Germany, France, Canada, Italy and all other countries." Furthermore, "this foundation construction method has already been implemented in some two hundred places for various construction projects including high-rise buildings, high towers, chimney stacks, abutment piers, water-tank towers, diesel engine stands, blast furnaces and the piers of elevated railroads." The highlight of the booklet is the 228 construction projects listed at the end. From this, we can see that these works spanned not only the entire Kinki region but ran through Shikoku, Nagoya, and Tokyo as well.

In other words, the Takechi family was part of the nouveaux riches that had amassed enormous wealth through the creation of so-called Dai-Ôsaka (the Greater Osaka). This is what contrasted so sharply with the Kônoike family after the Edo era. 
jointly directed the highly popular giday kyôgen $^{(6)}$ Taikôki Jûdanme at the Sôzô Gekijô run by Ôtani Hirotarô I (later Nakamura Jakuemon IV, 1920-2012).

The program, titled Sôzô gekijô dai-1 kai shien (First Trial Performance at the Sôzô Gekijô), was shown from 5 p.m. for three days, May 27, 28, and 29, in 1940. It included three pieces: Taikôki Jûdanme directed by Kônoike and Takechi; Inaka michi (Country Road), written by Sakanaka Masao and directed by Umemoto Shigenobu; and Lord Dunsany's King Argimenes and the Unknown Warrior, translated by Matsumura Mineko and directed by Kurihara Kazuto.

The fact that the names of the lighting and effects crew were recorded under the staff for Taikôki Jûdanme was an extremely rare point for classical kabuki.

Kônoike's description of the direction was as follows.

It goes without saying that all gidayu kyôgen plays derive from the puppet theatre (ningyôjôruri or bunraku). Thus the performance's foundations had all been completed by that time [when the ningyô jôruri was first produced]. This is called " $f \hat{u}$ " in gidayu, that is, the art of the narrator and the shamisen player who had composed the music and premiered it based on their interpretation of the text written by the jorruri author. This is what is strictly followed as the artistic framework of the play and what forms the goal of the gidayu performers' practices; the music's tempo and breath is what becomes tradition. In other words, the correct rendering of the gidayu bushi directs the play. This rendition of Taikôki Jûdanme was directed based on the correct giday $\hat{u}$ bushi and attempts to present the authentic giday $\hat{u}$ kyôgen...

From the fact that these words on the play's direction were written solely by Kônoike, it was likely Kônoike who led the direction. At the same time, casting was also Kônoike's responsibility.

These were not the only words from the directors and, perhaps expecting opposition, it was expressly noted at the end - under the joint names of Kônoike and Takechi -that, while some points about the performance ignored the aims of conventional kabuki, this was all done based on the directors' interpretation of the work.

In regards to the production of this play, an exceptionally detailed report was made by Atsumi Seitarô in the July 1940 issue of the theatre magazine Engei gahô (Performance Illustrated), which tells us that the play's direction deviated from that of traditional kabuki and that it drew closer to the script/ production of bunraku. And, as both the directors predicted, there was great positive and negative response to the play, about which Takechi would write at a later time.

After this production experience and losing the 31-year-old Kônoike from disease contracted during the war, Takechi later chose the likewise popular giday $\hat{u}$ kyôgen works, Kumagai jinya (from Ichitnoani futaba gunki) and Nozaki mura (from Shinpan utazaimon), for his first show in reexamining kabuki. This choice may be understood as a sequel to the aforementioned production and as a form of carrying out the wishes of his deceased mentor. And because this was received as a highly innovative work, it was only natural that the core of Takechi Kabuki would come to be understood as giday $\hat{u}$ kyôgen.

(6) Kabuki play based on a work from bunraku. 
Takechi's basic policy, setting aside that of transmitting the kabuki tradition, was to return to the original text and employ bunraku's tempo and acting/production method on stage. This was done in order to objectively "reexamine" kabuki, eliminate the superfluous frills that had developed during the process of transmission and gain a full grasp of the drama's structure.

The giday $\hat{u}$ kyôgen genre most readily followed the "doctrine of the original work," as developed by Takechi in his critiques and reviews. This was because the ningyô jôruri script was published. Unlike the kabuki script, which had been passed down as a handwritten copy in the theatre troupe's documents since the Edo era and had therefore created many variants per production, the ningyo jôruri script was easier to use when setting goals to return to. In other words, it offered a model of an original classic that was easy to specify.

If the first Takechi Kabuki had an extremely large impact on some, it was because its on-stage acting/ production almost coalesced with the theories that Takechi had hitherto published as a critic. There was already such a long-standing tradition in bunraku and kabuki performances that standard versions had long been established; it thus came as a surprise that Takechi's interpretation of the script and his direction (plus Bandô Minosuke VI's instructions for the actors) solidified a new production method completely removed from the standard. Dômoto Masaki, who viewed this first showing, described this in the following way, - "Verified truth is infinite possibilities. If one tries, one can do anything. Takechi's vision sits on the tail of his theory. It gradually develops in a dope tray, and forms itself, until it is printed with a right perspective. Since I know this process, I naturally regard the present kabuki as something lacking" (Kari no hane no kagayaki).

However, there is already a hint of Takechi's bluffing (a chronic problem in his later years) in his own words explaining his first production of Nozaki mura. An article titled "Tokushû: Kabuki saikentô zadankai" (Feature: Symposium on the Reexamination of Kabuki) was included in the 25th issue of the magazine Kanshô (Contemplation; February 10, 1950), published by a literary coterie led by Takechi. Unlike the more formal Makuichi, there is a certain joy to hearing the members' laughter in Kanshô; however, reading Takechi's commentaries on the two lovers' acting (in which metaphors for "sexual techniques" are used for each of their movements) with an understanding of Takechi's later years, also arouses the exasperated thought, "not this again." Those who say that Takechi "spoiled his whole honorable career by shooting pornographic films in his last days" are thus only turning a blind eye to the fact that Takechi had been responsible for scandalous statements since his golden days.

Furthermore, in order to arm such statements with a theoretical backing, Takechi added declarations like, "it's very Freudian and speaks to the unconscious minds of the audience." Yamaguchi Kôichi of the Ôsaka Mainichi Shinbun, who had long held an anti-Takechi position prior to this occasion as well, expressed a rather instinctive aversion during the Makuuchi discussion that Takechi also attended, ${ }^{(7)}$ stating, "Returning to the published giday $\hat{u}$ script means basing the play on the lyrics of the gidayû bushi, but this is accompanied by Takechi's interpretation and, frankly speaking, I have doubts about this point." This kind of sentiment, on the other hand, is also quite understandable.

However, I must also add that, while Takechi's theory-centered mind and its materialization in his productions as well as his arrogant manner of speech and statements that incurred disapproval may portray him as an aggressive character and a dogmatic idealist cum perfectionist, those who met

(7) "Kansai jikken gekijô wakate kabuki gappyô zadankai" (The Kansai Experimental Theatre: Round-table Discussion and Joint Review of Kabuki by the Younger Generation). 
Takechi Tetsuji in person all say that they have never met a more modest man.

This is a statement from a later production, but people have also stated that no other production experienced as little stagnation as Takechi's. In other words, in Takechi's productions, actual progress did not stop at logic and theory, and the drama unfolded successfully within the set amount of time. This made Takechi a professional who was able to achieve his goals with a minimum of necessary compromises.

While it is a bit dangerous to apply Takechi's later impressions to his starting point as a director and it would be more desirable to accrue a greater number of testimony, Yamada Shôichi, for instance, stated the following about Takechi Kabuki at the time: "A casual idea I uttered was adopted and, by the following day, it was backed by eloquent theory". ${ }^{(8)}$ In other words, rather than overly focusing on the integrity or consistency of Takechi's theoretical points, like his statements on Freud, which no longer sound very appealing, it is more fruitful to think about what he tried to accomplish in his challenge to transmit the kabuki tradition.

As a side note, the reputation of "Takechi Kabuki," begun in this way, would reach Tokyo some time later. An early example of this response in Tokyo making the news is an article in the September 22, 1950 issue of Tôkyô Shinbun, "Kansai de chûmoku sareru hanagata kabuki" (Young Stars' Kabuki in the Kansai Area). It is worthy to note that this article not only reveals the circumstances on the eve before the tumultuous popularity of "Takechi Kabuki" but also simultaneously depicts its modest audience explicitly with the phrase, "sixty-percent attendance." The name "Takechi Kabuki," surprisingly, does not surface in this article.

\section{Deviation from the "Doctrine of the Original"}

The genres of kabuki that Takechi engaged in varied widely from the aforementioned first to third phases; however, the giday $\hat{u}$ kyôgen genre decreased, especially after the third phase. Takechi's later Chikamatsu pieces were based on ningyô jôruri works. Many of them, though, were jôruri revivals because the works had already ceased to be transmitted in the bunraku tradition.

$\square \quad$ Meido no hikyaku (The Courier for Hell) (some scenes had been inherited in the oral tradition of bunraku, but not kabuki)

$\square \quad$ Yuriwaka daijin nomori no kagami (The Mirror of the Great Lord Yuriwaka's Field Watch) (transmitted neither in the bunraku nor the kabuki tradition)

$\square \quad$ Futago Sumidagawa (The Twins and the Sumida River) (only one scene had been passed down in the bunraku tradition; in kabuki, the revival by Ichikawea Ennosuke III took precedence)

In other words, the method adopted by first phase Takechi Kabuki could no longer be realized in the third phase. I have already noted that the reason why the first Takechi Kabuki, Kumagai jinya and Nozaki mura, had such a great impact on some was that Takechi's interpretation of the script and his production (as well as Bandô Minosuke's acting instructions) solidified a new production method com-

(8) Pamphlet for Sôzō gekijô dai-1 kai shien (Trial Performance for the First Sôzô Gekijô). 
pletely removed from the standard. Works with no recorded history of transmission that have been created in the form of revivals cannot be argued in the same breath as works that have "reexamined" the production methods of an existent standard.

There were actually some pieces that Takechi produced during his first phase that were already removed from his "doctrine of the original" stance. The most obvious example was Ishikiri Kajiwara.

Ishikiri Kajiwara is a gidayû kyôgen based on a puppet theatre work entitled Miura no Ôsuke kôbai tazuna; however, it was no longer transmitted in the gidayu bushi tradition. In kabuki, its script had been largely rewritten at the start of the 19th century when it was revived in Osaka, and the modest work had been remade into a flamboyant one. It had later become a popular play performed after the Meiji era in Tokyo as well. In other words, while this piece was a gidayû kyôgen, it had no classical bunraku standards to return to and its transmission in kabuki had roots separate from the original jôruri work. How then did this correspond to Takechi's standpoint of "reexamination"? According to an interview with Tomijûrô, its leading actor at the time (as Bandô Tsurunosuke), the way to restore, not Miura no Ôsuke kôbai tazuna, but Ishikiri Kajiwara was to establish the kata (forms/patterns) created by Ichimura Uzaemon XV (1874-1945) as the foundation for revival.

The classical standard here had already shifted from "the original work" to the kata in which the piece was performed. Tomijûrô explained that it all depended upon "choosing the most appropriate kata for reviving the work to the greatest possible extent." Still, there is doubt as to whether it was truly acknowledged in this way at that time. Even after Takechi's death, Yoshikazu Gondô, one of the people closest to Takechi in the 1950s, stated that it was always incomprehensible why Takechi would have adopted the kata of Uzaemon, whom he had always hated. ${ }^{(9)}$ If it were incomprehensible, the only other question remaining is that Takechi threw out his stance on the "doctrine of the original."

It was due to such doubts that criticism of Takechi increased during his second phase. Because this phase included works that did not have the standard of those in his first phase, Takechi had to search for various compromises. And, perhaps because of the biased impression that he had surrendered at the gates of Shôchiku ${ }^{(10)}$ or because of the retrospective glorification of Takechi's first phase, at a time when criticism focused on those who would sell their soul to "capitalism" in a "commercial theatre," Takechi's ardent admirers came to harbor a distrust against him, forming a most unfortunate disconnect.

To give an example, the following five acts constituted the September 1962 production of Imoseyama onna teikin at Tôyoko Hall: "Emishiyakata" (The House of Emishi); "Sugi sakaya" (The Sake Dealer); "Michiyuki” (Lover’s Journey); "Mikasayama goten” (The Mansion at Mikasayama Mountain); and "Iruka chûsatsu" (The Murder of Iruka). "Emishiyakata" and "Iruka chûsatsu" had never become traditional part of kabuki tradition, so, rather than being revivals, these acts were closer to new creations. Thus Takechi, true to his boastful nature, never forgot to aggrandize himself while searching for compromises in the reality of performance; he declared that he would produce each of the scenes in a different acting style, ${ }^{(1)}$ adding changes to the original work in the actual production. A considerable amount of criticism ensued over this kind of attitude at the time:

(9) Gondô Yoshikazu, Takechi Tetsuji no kabuki enshutsu (Takechi Tetsuji’s Kabuki Direction).

(10) A statement made by Imao Tetsuya at the discussion "Takechi Kabuki to sono jidai” (Takechi Kabuki and Its Times).

(11) Tôkyô Shinbun, August 21, 1962. Quoted in Fujita Hiroshi’s "Wankyoku sareta Imoseyama fukkatsu" (The Revival of a Distorted Imoseyama) (Engekikai, October 1962). 
Somehow or other, the great Takechi Tetsuji seems to thoroughly know "old production practices." He also seems to have some delusions of grandeur. His talent for reviving old production practices that do not even exist in the original works is nothing short of admirable. As inexperienced as I am, I have watched the play consulting the original script line by line, and reminisced about the drama critic who once preached the doctrine of the original... Takechi has stated that this performance and Takechi Kabuki are separate things; this shows his conversion from a socialist to a capitalist to an authoritarian. It means that Takechi has no ideological background. It is an obvious fundamental principle that the original work be prioritized at all times in the recreation of kabuki. Takechi's attitude of easily changing this principle on the excuse of being "in the realm of commercial theatre" is simply detestable. ${ }^{(12)}$

There were, however, many aspects to the performance that were acknowledged in later years, as can be seen in Dômoto Masaki's recollection that "the richness of movement not simply confined to the text, as is often the case with revival works, left a deep impression." ${ }^{13)}$ However, the opinion that Takechi Kabuki was "inexcusable" still surfaced at the time, not as much because of principle but more because of the sentiment that everybody's beautiful memories and aspirations had been debased.

The Tsuruya Nanboku IV pieces that Takechi worked on during his third phase faced even greater challenges than Imoseyama onna teikin. Not a single work of kabuki can be performed exactly in accordance with the original; some (in most cases, considerable) revision and reduction becomes necessary; this, today, is common sense. Revision and reduction cannot escape the fact that they, of course, are accompanied by the realities of the performance, the time restrictions, cast, cost, and unspoken rules and circumstances. These would only further distance Takechi's future works from those of his first phase.

Kabuki developed with different texts depending on the actors and the performance. Moreover, it was not restricted to a single theatrical company, like bunraku, and had many variations from the Kanto region to the Kansai region to the small theatres (koshibai). On the other hand, bunraku was almost fully based on a single text reliant on the original work. At the same time, the decline of bunraku had left the Osaka Bunraku-za as the single remaining bunraku theatre troupe, and this luckily worked in favor of Takechi's theories.

On top of this, bunraku had Yamashiro no shôjô Toyotake, a figure that Takechi could wholeheartedly rely upon in his focus on theory and tradition. Takechi also tried to find the same figure in kabuki's Onoe Kikugorô VI (1885-1949); however, Kikugorô VI is later known to have said, "He [Takechi] tells me to do things that cannot be done."

Bunraku was colored in the singular style of Yamashiro no shôjô. It was a style that was rather modest in character, simple, intellectual, and compact. It was not that Takechi's contact with the bunraku world did not arouse opposition, and it is important to note shamisen player Tsuruzawa Jûzô

(12) Fujita Hiroshi, "Wankyoku sareta Imoseyama fukkatsu" (The Revival of a Distorted Imoseyama).

(13) Dômoto Masaki, "Ryûtôdabi no Imoseyama" (Imoseyama's Anticlimax) (Engekikai, December 1983). 
IV's testimony that Yamashiro no shôjô changed after his contact with Takechi. ${ }^{(14)}$ However, with the waning tradition of bunraku, its path to survival as a form of classical theatre was not so distant in nature from the path proposed by Takechi (it is a different matter whether current bunraku still exists on the path of classical theatre).

In this sense, while Takechi's name has spread as a kabuki director, what he advocated was closer to that of a bunraku theorist. In nô and kyôgen, deviations that result from special forms of direction or differences in the traditions of the various schools must be acknowledged. The only form of classical theatre that could build on an absolute text was bunraku. Kabuki, on the other hand, had pursued a path towards surviving as a form of present-day commercial theatre before it could reach a decision on whether to follow the path of classical theatre or search for the means of doing so. And when Takechi attempted to direct this form of theatre within such a commercial realm, it was only inevitable that he would repeatedly let down his first phase Takechi Kabuki followers. This explanation may help expose the rest of Takechi's activities, other than those of first phase Takechi Kabuki.

I say this because, frankly speaking, it is nearly impossible, even from the nature of the works, to judge the events after the second phase on the principles of the first, and it is uninteresting to avoid any and all evaluation but denial layered upon denial. The allure of Takechi was different for each of the generations that Takechi encountered during his second, third and fourth phases. The subject of this paper focused on the first phase. It may be, however, that transcending the intense first phase followers and searching for the potential and lure of his second phase onwards is the path towards further revitalizing Takechi Tetsuji in the future.

\section{Postscript: "A Return to Absence": The Coexistence of the Practitioner and the The- orist}

Lastly, as a means of further emphasizing the appeal of the contradictory Takechi, I would like to add in this postscript a few more remarks that did not find their way into this paper.

First of all, the direction and policy of first phase Takechi Kabuki, as Dômoto noted, was not a "verified truth." The history of theatrical performances uncovered after Takechi's time has made it clear that kabuki performances based explicitly upon the original giday $\hat{u}$ script (maruhon) and tempo of bunraku had never existed in the history of kabuki. In this sense, Takechi Kabuki was an experiment to "return" to an ideal state that had never existed and would never exist at any other point.

It was, however, a definitely worthwhile experiment. The effectiveness of the techniques invested in this experiment, especially the technique of holding the breath, was proven in later performances by Nakamura Tomijûrô and Sakata Tôjûrô. Onoe Baikô VII (1915-1995) also later emphasized, separate from Takechi, that holding one's breath is the key. Of course, this may have followed from the fact that Baikô was the successor to Kikugorô VI, to whom Takechi was devoted.

Furthermore, Takechi's strict "doctrine of the original," which carefully weighed each word and phrase, changed the interpretation of future jôruri works from its very roots.

Secondly, there has been no other theorist who took such a comprehensive view of performance history and defined it in such concrete terms as Takechi Tetsuji. A famous declaration in Takechi

(14) Tsurusawa Jûzô, Bunraku no shamisen: Tsurusawa Jûzô kikigaki (The Shamisen in Bunraku as Told by Tsurusawa Jûzô) (Kokuritsu Bunraku Gekijô Chôsa Yôsei-ka; March 1986). 
kabuki no enshutsu (The Direction of Takechi Kabuki) ${ }^{(15)}$ explains that kabuki is not a theatre based on a single style but is rather an overall name for some twelve varieties of performance styles. We may be inclined to make fun of this saying that "Takechi Kabuki also did not follow a single style," however, Takechi's boast about the aforementioned Imoseyama of 1962 - that "first comes the classical direction, then the direction from the middle ages; 'Michiyuki' follows the original work [=ningyô jôruri] and the ending is based on kabuki direction from the end of the Tokugawa shogunate" - shows there was no other person who understood kabuki as it changed during the various periods, or who could materialize it in such a way.

Takechi emphasized that there was a style, a standard and a tradition worth reviving in each of the twelve variations and that each must be understood separately. His was a history of kabuki based on styles, which led to an attempt at performance history. It is especially laudable that this was done before the publishing of Ihara Seiseien's Kabuki nenpyô (The Chronology of Kabuki) (August 1956 - May 1963, Iwanami Shoten), an invaluable resource for understanding the details of kabuki history.

However, it is still uncertain whether these twelve types of traditions were truly forms preserved within kabuki. Bunraku, on the other hand, has retained "fü," or styles adopted by its first performers and those who perfected them; because Yamashiro no shôjô himself is said to have been the expert in research and studies on fû, bunraku can be considered to once again offer a more sturdy foundation on which to develop theories on acting and musical performance history. Takechi's Fû no rinri (The Ethics of $F \hat{u})^{(16)}$ is certainly one of his representative works and one of everybody's top five Takechi texts. Its primary focus is that art is a battle against restrictions and that the expressions of bunraku take on an artistic quality only within the realms of fû standards. In simpler terms, it was an artist training theory that stated that making "something simple to do" "not so simple to do" and making it look as though it were "simple to do" is the path to training oneself. Takechi would later adopt this theory for kabuki as well and would write a little-known text entitled Kata to engi (Kata and Acting), which explained "kata no rinri" (the ethics of kata). ${ }^{(17)}$ Takechi's theories of retracing back to the origins in kabuki's kata were also developed in all directions in his discussion with Mitsugorô VIII in Geijûya (Ten Nights of Talking about Art). ${ }^{(18)}$ Although it was interesting in and of itself, compared to bunraku, kabuki was inconsistent and impure, and it was in this chaos that it had a value different from that of bunraku.

However, Takechi always managed to come out on top and he found the means of reviving the lost tradition of kabuki in the overall history of theatre. For instance, if no tradition of Genroku kabuki remained from Sakata Tôjûrô I (1647-1709), he would examine the form of kyôgen theatre and try to work reconstructively from there. This attitude towards pursuing an outlook not only by viewing the comprehensive history of kabuki but the entire history of Japanese performing arts, including nô, kyôgen, jiuta, and so on, was the greatest achievement propounded by Takechi as a theorist.

This outlook is adequately summarized once again by Dômoto Masaki. Referring to the magazine

(15) Takechi Tetsuji, "Takechi kabuki no enshutsu” (The Direction of Takechi Kabuki). (Dentô Geijutsu Kôza Vol. 2: Kabuki Bunraku (Kawade Shobô, August 1955).

(16) Takechi Tetsuji, "Fû no rinri" (The Ethics of Fû), compiled in Kabuki no reimei (The Dawn of Kabuki) (Seisensha, July 1955).

(17) Takechi Tetsuji, "Kata to engi” (Kata and Acting), in Kokubungaku kaishaku to kyôzai no kenkyû (Japanese Literature: Studies in Interpretation and Teaching Materials; extra edition, June 1975).

(18) Bandô Mitsugorô and Takechi Tetsuji, Geijûya (Shinshin dô, October 1972). 
Kanshô, he wrote, "the same person conducted his 'nô critique,' 'kabuki critique,' and 'shingeki ${ }^{(19)}$ critique' under the same sensibility". ${ }^{(20)}$ Although Kanshô was not a magazine run solely by Takechi, no other statement better describes Takechi's attitude in such a simple manner. And, regarding whether this kind of standpoint is now shared within the realm of criticism, research, or the audience, we can say that Takechi Tetsuji's goals still lie in the future.

Thirdly, it must be noted that it is an overstatement to say Takechi Tetsuji was well versed in all forms of technique. For instance, in regards to Tôjûrô's rehearsal for Narukami, Dômoto Masaki notes that, while he thought Takechi's model performance was "good," he also raised doubts about Takechi's unverified emphasis on the acting of Narukami to the effect that "there is an oral tradition to say these lines as if one were across a valley." "Although it is a classical kabuki piece, it was one that was revived by [Ichikawa] Sadanji II (1880-1940)," he noted. ${ }^{(21)}$

This is another of Takechi's questionable qualities. Yet, there was still a certain necessity to Takechi's speech. Matsui Kesako's observations hit the mark here:

Because Takechi has been an active practitioner since his early days, most of his "interpretations" have been formed from the standpoint of effectiveness in practice. In other words, the "interpretation" considered most effective at that point was actually adopted in the process of the actor filling out his role. While this is a natural course of action for a practitioner, it was because such remarks, as so-called "excuses," intermingled with his original remarks as a theorist that Takechi's position as a theorist was threatened. This is also why it is extremely dangerous to comment on the details of remarks left posthumously by Takechi. ${ }^{(22)}$

This trait likely surfaced not only during Takechi's rehearsals but, to varying degrees, in all aspects of his activities as well, such as his theories on film, tradition and ancient history. Even with his commentary on Kumagai jinya, his finest critique of his work at the time, both in terms of the completeness of the interpretation and its realization, Takechi contradicts himself by stating to whom Kumagai delivers his narrative (monogatari) at the climax of the first half. At one point, Takechi stated, "there are some with the opinion that he presents his monogatari so Kagetaka Kajiwara, listening in from behind, will hear. This, however, ... is a mistaken interpretation". ${ }^{(23)}$ On the other hand, he also nonchalantly states in his discussion with Mitsugorô that "the piece is about telling the narrative to Kajiwara". ${ }^{(24)}$ It is apparent that it is useless to pursue consistency and it is better to see all of these contradictions as the allure of Takechi Tetsuji.

To offer a somewhat more malicious example, there was a shamisen master called Tsurusawa Seiroku III (1868-1922) who had trained the young Yamashiro no shôjô (Kotsubodayû at the time). He had passed away in 1922 when Takechi was still young, but Takechi could still listen to some of his

(19) Western-style theatre.

(20) "Afterword," in Dômoto Masaki, Zeami. (Geki shobô, April 1986).

(21) Statement made at the discussion "Tada Yûji ni kiku" (Learning from Yûji Tada) by Imao Tetsuya, Kondô Yoshikazu, and Dômoto Masaki in Kabuki kenkyû to hihyô, No. 24, December 1999).

(22) Matsui, Kindai no Gyakush $\hat{u}$.

(23) Takechi, "Kumagai Kentô" (Examination of Kumagai jinya) in Kabuki no Reimei.

(24) Geijûya. 
records.

NHK Radio once invited Takechi to speak on the title, "Omoide no gei to hito: sandaime Tsurusawa Seiroku" (Remembrances of Arts and People: Tsurusawa Seiroku III) (for a program broadcast October 20, 1978). The selection played was the latter half of Kumagai jinya. After listening to the selection, Takechi commended it highly, stating, "It's just great. This kind of work simply does not exist today. The shamisen is so orderly, no matter how much it is played, it never loses its ma (intervals). This is highly powerful."

However, Yamashiro no shôjô and Seiroku III never recorded Kumagai jinya together. Yamashiro no shôjô only recorded the entire Kumagai jinya with Tsurusawa Tôzô in his later years; before the war, he recorded it with Seiroku IV (1889-1960) on a special disc called a long-playing record (which required a special device to play properly). ${ }^{(25)}$ In other words, the music broadcast during the radio program was a recording of Seiroku IV played at the wrong frequency.

You may wonder how this could happen to someone like Takechi Tetsuji, but, on the other hand, remembering Seiroku III from other records, I know no other commentary with as appropriate a description made in so little words. While his commentary does start on the wrong foot, its content most definitely does not fall short of the truth. So, how should this be interpreted?

Takechi was sharp-witted, and could be highly persuasive; he could also be deceptive and untruthful. It is within this entire monumental presence that I feel lies the true attraction of Takechi Tetsuji.

\section{References}

1) BANDÔ, Mitsugorô and TAKECHi,Tetsuji. (1972). Geijûya, Shinshin-dô Publishing.

2) CD Set. (2006). Fukugen maboroshi no chôjikan rekôdo Yamashiro no shôjô Taishô - Shôwa no bunraku wo kiku (Revival of the Rare LP Record: Listening to the Taishô/Shôwa Bunraku of Yamashiro no shôjô), Kinokuniya Publishing.

3) DÔMOTO, Masaki. (1971). "Kari no hane no kagayaki" in Dentô engeki to gendai" (Classical Theatre and Modern Times), San-ichi Shobô Publishing.

4) DÔMOTO, Masaki. (1983). "Ryûtôdabi no Imoseyama" (Imoseyama's Anticlimax), Engekikai, December 1983.

5) DÔMOTO, Masaki. (1986). "Afterword” in Zeami, Geki shobô Publishing.

6) FUJITA, Hiroshi. (October 1962). "Wankyoku sareta Imoseyama fukkatsu" (The Revival of a Distorted Imoseyama), Engekikai. Originally appeared in Tôkyô Shinbun, August 21, 1962.

7) GONDÔ, Yoshikazu. (1989a). “Takechi Tetsuji no kabuki enshutsu” (Takechi Tetsuji's Kabuki Direction), Kabuki kenkyû to hihyô (Kabuki Research and Critique), Volume 3.

8) GONDÔ, Yoshikazu. (1989b). "Takechi Tetsuji shiryô shûsei” (Collection of Documents on Takechi Tetsuji), Kamigata Geinô (Kamigata Performing Arts), Volume 100.

(25) In regards to the long-playing record, see the three-disc CD set, Fukugen maboroshi no chôjikan rekôdo Yamashiro no shôjo Taishô - Shôwa no bunraku wo kiku (Revival of the Rare LP Record: Listening to the Taishô/Shôwa Bunraku of Yamashiro no shôjô; Kinokuniya, 2006). 
9) IMAO, Tetsuya, GONDÔ,Yoshikazu, DÔMOTO, Masaki, YAMADA,Shôichi and ATSUMI, Seitarô, (December 2000). "Takechi Kabuki to sono jidai” (Takechi Kabuki and Its Times), Kabuki kenkyû to hihyô (Kabuki Research and Critique), Volume 26.

10) IMAO,Tetsuya, GONDÔ,Yoshikazu, and DÔMOTO,Masaki. (December 1999). "Tada Yûji ni kiku" (Learning from Yûji Tada), Kabuki kenkyû to hihyô (Kabuki Research and Critique), Voulme 24.

11) MATSUI, Kesako. (1989). “'Kindai' no gyakushû” (Modern Times' Counterattack), Kabuki kenkyû to hihyô (Kabuki Research and Critique), Volume 3.

12) Pamphlet. (December 1949). Kansai jikken gekijô dai rokkai kôen wakate kabuki (Kansai Experimental Theatre Sixth Showing: Kabuki from the Younger Generation), Osaka, Bunraku-za.

13) Preface to the booklet. (February 15, 1932). Tokkyo Takechi-shiki kiso kô ni tsuite (About the Patented Takechi-style Foundation Work).

14) SEKI, Itsuo. (January 1950). "Kansai jikken gekijô wakate kabuki gappyô zadankai" (The Kansai Experimental Theatre: Round-table Discussion and Joint Review of Kabuki by the Younger Generation), Makuuchi.

15) Statement made in the discussion. (February 1950). "Nagareru kabuki wa ikite iru" (Flowing Kabuki is Living Kabuki), Makuuchi.

16) TAKECHI,Tetsuji. (February 10, 1950). "Tokushû: Kabuki saikentô zadankai" (Feature: Symposium on the Reexamination of Kabuki), Kanshô (Contemplation).

17) TAKECHI, Tetsuji. (1955a). "Fû no rinri" (The Ethics of Fû), compiled in Kabuki no reimei (The Dawn of Kabuki), SeisenshaPublishing.

18) TAKECHI, Tetsuji. (1955b). "Kumagai jinya kentô" (Studying Kumagai jinya), compiled in Kabuki no reimei.

19) TAKECHI, Tetsuji. (1955c). "Takechi kabuki no enshutsu" (The Direction of Takechi Kabuki), Dentô Geijutsu Kôza, Volume. 2: Kabuki Bunraku, Kawade Shobô Publishing.

20) TAKECHI, Tetsuji. (June 1975). "Kata to engi” (Kata and Acting), in Kokubungaku kaishaku to kyôzai no kenkyû (Japanese Literature: Studies in Interpretation and Teaching Materials; extra edition).

21) Theatre Review. (September 1940). "Kansai de chûmoku sareru hanagata kabuki" (Young Stars' Kabuki in the Kansai Area), Tôkyô Shinbun.

22) TSURUSAWA, Jûzô. (March 1986). Bunraku no shamisen: Tsurusawa Jûzô kikigaki (The Shamisen in Bunraku as Told by Tsurusawa Jûzô), Kokuritsu Bunraku Gekijô Chôsa Yôsei-ka.

23) YAMADA, Shôichi. Pamphlet for Sôzô gekijô dai-1 kai shien (Trial Performance for the First Sôzô Gekijô).

24) YAMAGUCHI, Kôichi. (January 1950). "Kansai jikken gekijô wakate kabuki gappyô zadankai” (The Kansai Experimental Theatre: Round-table Discussion and Joint Review of Kabuki by the Younger Generation), Makuuchi. 